\title{
Chemical method of eliminating odors in commercial pig production
}

\author{
(C) Larisa V. Pilip, ${ }^{*+}$ and Maria E. Kazakova \\ Chair of Zoohygiene, Physiology and Biochemistry. Vyatka State Agricultural Academy. \\ Oktyabrsky Prospect, 133. Kirov, 610000.Russia.Phone: 9991008078. E-mail: pilip_larisa@mail.ru
}

\begin{abstract}
*Supervising author; ${ }^{+}$Corresponding author
Keywords: sulphuric acid, industrial pig farming, technological scheme, odorigenic substances, sodium hypochlorite, emission, swine manure.
\end{abstract}

\begin{abstract}
According to the Federal Waste Classification Catalogue swine manure and slurry are classified as hazardous wastes of class 3 . When stored these wastes emit various gases into the atmosphere including greenhouse gases. It is possible to solve this problem by using a chemical approach. For binding pollutants of acidic nature it is proposed to use sodium hypochlorite showing the properties of bases, while for the substances having basic properties it is possible to use sulfuric acid. The distinctive feature of this method is the technology of using the wastes of chemical industry. This paper proposes and justifies the technological scheme of the chemical method for cleaning the air polluted by emissions from industrial pig enterprises. The research was performed under laboratory conditions, taking into account the technological specifics of pig industry. In the course of the study, gravimetric and potentiometric methods were used. The object of the study was native manure obtained from 4-month-old pigs. In the experiment, we used waste sulfuric acid and alkaline solution of sodium hypochlorite produced By "HaloPolymer Kirovo-Chepetsk". The handbook of best available methods in pig industry recommends using low-waste technologies, while it is possible to use waste products from local chemical enterprises for recycling agricultural waste. The technological solution will make it possible to reduce the concentration of odorigenic substances in the air of livestock premises, to eliminate odors from ventilation emissions, to reduce the toxicity of manure effluent and to process toxic fresh pig manure into granular organic fertilizer. The introduction of this scheme into industrial pig farming will dramatically reduce the amount of malodorous animal waste, significantly reduce odor pollution and improve the environmental situation in the areas adjacent to pig farms.
\end{abstract}

\section{References}

[1] V.I. Gaiduk, G.V. Komlatskiy. Factors of reducing the impact of industrial pig farming on agricultural ecosystem. Proceedings of the XI International Scientific and Practical Conference: $21^{\text {st }}$ Century: Fundamental Science and Technology. Krasnodar. 2017. P. 201-207. (russian)

[2] S. Kakareka, A. Malchikhina. Ammonia in the atmospheric air: origins, concentration, regulation. Monography [Текст]. Minsk. 2016. 256p.

[3] L.V. Pilip, T.Ya. Ashichmina. Wastes of industrial pig farming - challenges and solutions. Proceedings of XV All Russian Scientific and Practical Conference with International Participation «Biodiagnostics of Natural and Technogenic systems». Vyatka State University, Institute of Biology of

Komi Scientific Center (Ural Branch of the Russian Academy of Sciences). Kirov. 2017. P.180-183. (russian)

[4] Collection of reports on emission of pollutants into the atmospheric air by industrial enterprises. Volume 3. Donetsk. 2004.

[5] L.V. Pilip, N.V. Syrchina New approaches to deodorization of pig manure. Hippology and veterinary medicine. 2018. No.4(30). P.99-106. (russian)

[6] C. Lingshuang, J.A. Koziel, K. Brian, T. Steven. Effects of Dietary Treatment on Odor and VOCs Emitted From Swine Manure. Animal Industry Report. 2009. AS. 655. ASL R2437. DOI: https://doi.org/10.31274/ans_air-180814-952.

[7] N.V. Kleymyonova, T.V. Smagina, S.N. Khimicheva. Therapy of cannibalism effects in industrial pig farming. Bulletin of Agrarian. Orel SAU. 2016. No.2(59). P.84-88. (russian)

[8] A.P. Pavlov, P.V. Grishin, V.Kh. Grishin, E.L. Lappo. Air cleaning technique used in animal premises. Russian Patent No 2573955. 2013. (russian) 
[9] Yu.N. Terentyev, N.V. Syrchina, T.Ya. Ashichmina, L.V. Pilip. Reducing emissions of odorigenic substances under conditions of industrial pig farms. Theoretical and Applied Ecology. 2019. No.2. P.113120. (russian)

[10] Methodical recommendations on designing the systems of disposal, processing, disinfection, storage and recycling of manure. Guidance Document of Agroindusrial Complex 3.10.15.01-17. Moscow. 2017. 154 p. (russian)

[11] Nozomi, Co. Ltd. Solution For Pig farm Odor [online] Engormix. 2008. URL: https://en.engormix.com/pig-industry/articles/pig-farm-odor-t34339.htm (дата обращения: 30.04.2020)

[12] T.Ya. Ashichmina, N.V. Syrchina, Yu.N. Terentyev, L.V. Pilip. Technique for eliminating odor of ventilation emissions from swine production facilities. Russian Patent No 2708599. 2019. (russian) 